\title{
NOTICIARIO
}

\section{THE EXAMINATION OF ANCIENT DNA: GUIDELINES ON PRECAUTIONS, CONTROLS, AND SAMPLE PROCESSING}

\author{
LA INVESTIGACIÓN DEL ADN ANTIGUO: DIRECTRICES SOBRE LAS PRECAUCIONES, \\ CONTROLES Y EL TRATAMIENTO DE LAS MUESTRAS
}

\author{
M. SCHOLZ (*) \\ L. TRELLISÓ CARREÑO $(* *)$ \\ C.M. PUSCH $(* * *)$
}

\section{RESUMEN}

La paleogenética se ha convertido en los últimos años en una disciplina coronada de éxito que ofrece grandes expectativas para el desarrollo de la investigación arqueobiológica. No obstante, la investigación paleogenética (p. ej: $P C R$, secuenciación delADN) de especímenes antiguos es susceptible de ser falsificada por la presencia de una contaminación más reciente. Actualmente sabemos que la contaminación que provoca la amplificación de secuencias "no auténticas" procede de las siguientes fuentes: (i) las biomoléculas humanas provienen de la persona que realiza el experimento genético o incluso también del arqueólogo $u$ otras personas que previamente hayan tenido contacto con el especimen; (ii) de secuencias de ADN edáficas derivadas básicamente del crecimiento bacterial o fúngico en el seno del especimen. La tercera fuente de contaminación puede surgir de las substancias (iii) empleadas para la conservación del especimen. El objetivo de este artículo consiste en aportar una serie de consejos sobre el modo correcto para tratar las muestras de material óseo prehistórico, en el caso que se pretenda realizar ulteriores exámenes biomoleculares. Con esta finalidad presentamos detalladamente las precauciones y condiciones necesarias de trabajo, así como una explicación de cómo puede controlarse la contaminación del ADN.

Resulta prometedora la introducción de las herramientas y de la metodología paleogenéticas en el marco de la investigación arqueológica. Tal y como se observa en la mayoría de las publicaciones recientes, existe un gran número de cuestiones que pueden beneficiarse del estudio paleogenético. Cabe citar, entre otras, por ejemplo, los métodos para la reconstrucción de las estructuras sociales 
en la Prehistoria (a saber, la determinación de las relaciones de parentesco), o ciertas aplicaciones de la investigación paleopatológica. Por otra parte, el repertorio de técnicas disponibles para el análisis delADN fósil, incluso del que está altamente degradado, permite elucidar, y en algunos casos dar respuesta, a antiguas cuestiones de interés general sobre la evolución de la humanidad. Con la ayuda de métodos más extensos y de un conjunto de técnicas de ADNa optimizadas eficazmente, la paleogenética, en tanto que joven disciplina, se establecerá por sí misma como un instrumento importante de la investigación arqueológica y antropológica. Sin duda alguna, la colaboración científica internacional permitiría una mayor y mejor aceptación de estos métodos en el seno de las disciplinas implicadas, así como fuera de ellas y, en consecuencia, llevaría a una mejor cualidad de la investigación dentro de las ciencias paleogenéticas. Cabe desear que en un futuro próximo se intensifique el intercambio de conocimientos y experiencias entre los grupos de trabajo que estudian las sociedades antiguas.

Key words: Ancient DNA. Bone samples. Palaeogenetic analysis. Contamination detection.

Palabras clave: ADN antiguo. Muestras óseas. Análisis paleogenéticos. Contaminación detección.

\section{INTRODUCTION}

The isolation and examination of the hereditary molecule deoxyribonucleic acid (DNA) from prehistoric and fossil bone samples has become one of the biggest challenges in prehistoric anthropology within the past years (Izagirre et alii, 1998; Pusch and Scholz, 1997; Pusch and Scholz, 1998; Pusch et alii, 1998; Scholz and Pusch, 1997; Scholzet alii, 1998). Traditionally, anthropologists use morphological features on human remains to directly assess information about the individuals' gender, age and the conditions under which they lived. Under good conditions of preservation of the bone morphology, statistical analyses of epigenetic variants (discreta) may allow anthropologists to make inferences about the genetic structure and thus, the kinship relations of prehistoric societies. However, it should be noted that a direct association between the genetic character of an individual and epigenetic variants has not yet been demonstrated (Hauser and deStefano, 1989; Scholz, 1996). In addition, scientists out of different research fields have begun to analyze prehistoric bone material with alternative me- thods. The analysis of trace elements for example has been used to determine patterns in nutritional practices in prehistoric populations (Sealy et alii, 1991). However, questions of kinship for example between individuals of a cemetery can be best adressed by the investigation of the fragmentary remains of residual DNA present in hard and soft tissues from archaeological sites (Hagelberg and Clegg, 1991; Scholz et alii, 1997a, b , c). Moreover, to determine the state of DNA survival within the hyaline collagen matrix of prehistoric bone, the investigation of the content of ancient amino acids and certain $\mathrm{D} / \mathrm{L}$ values thereof may be a necessary prerequisite (Poinar et alii, 1996).

Here we describe the handling of hard tissues (i.e. bone samples) derived from palaeontological specimens when further investigations on a molecular level are required. The guidelines described herein will help to meet a high quality standard to guarantee non-artefactual genetic analyses (e.g. DNA cloning, DNA amplification by the polymerase chain reaction (PCR)).

\section{aDNA PRESERVATION}

Encoded hereditary information (e.g. DNA polymorphisms and sequence variants) specific to every individual is stored in the mitochondria as well as the nucleus of every cell -and thus every sclerocyte- of the respective higher organism. After cell death, natural decomposition begins to degenerate the DNA macromolecule (i.e. polymer). The further decay of nucleic acids is dependant on weathering, soil chemistry and other biochemical reactions, such as hydrolysis or oxidation. Under certain and favourable conditions of preservation, various sized (low molecular weight) fragments of the original high molecular weight DNA may be preserved in bone. The presence of minute amounts of highly degraded nucleic acids requires the development of both sensitive and effective methods for the preparation of residual biomolecules out of prehistoric bone samples.

\section{ASEPTIC CONDITIONS}

In order to prevent possible contaminations when taking samples the following precautions have to be taken: All working steps are carried out under sterile conditions in a laboratory qualified for

T. P., 57, n. $^{\circ} 1,2000$ 


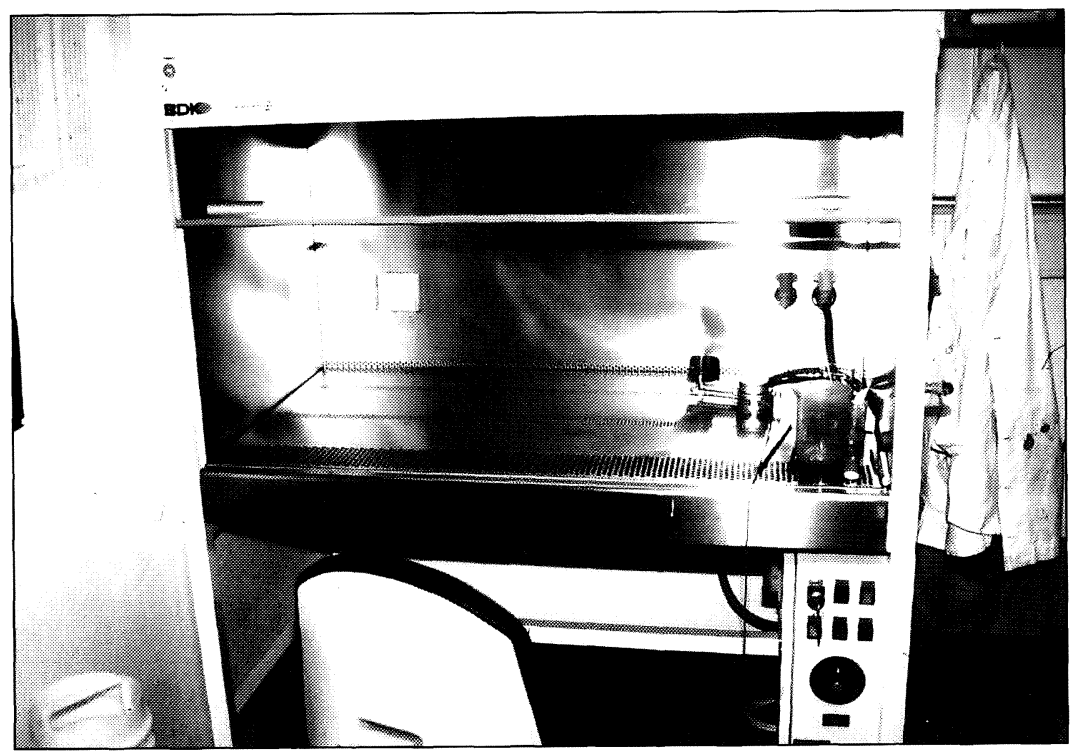

a)

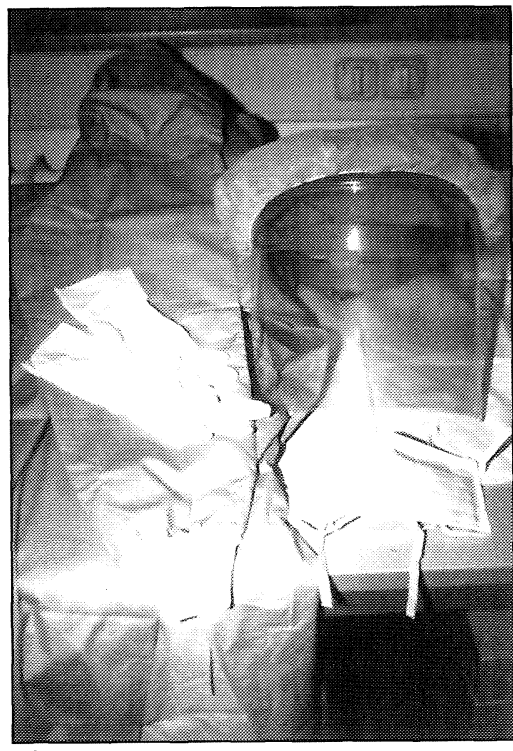

b)

Plate 1. a) Most steps of the working process have to take place in well separated laboratory rooms only. In order to guarantee sterile conditions and a subsequent contamination prevention, non-authorized persons are not allowed to enter these areas. Since biohazard chemicals are extensively handled and cloning procedures are possibly performed therein we recommend to declare the laboratories to S1 security zone. b) Special working areas (clean bench) and clothes (e.g. latex gloves and plexiglass face masks) are used for sample preparation and further analysis under sterile conditions.

molecular genetic analyses (Plate 1a). The use of personal protection wear out for the scientists and an appropriate laboratory equipment (e.g. clean bench (Bachofer), is a necessary prerequisite (Plate $1 \mathrm{~b}$ ).All appliances and containers used for working with or storing the bone material are cleaned from possible remaining bone powder residue in several steps (stone powder, acetone, propan-2-ol) before and after use. By irradiating the work area with UV$C$ light for approximately 6 hours it is free from amplifiable DNA fragments of any kind. Decontamination of the containers and instruments used was carried out in two stages with substances capable of dissolving DNA and DNases (DNAaway, Molecular Bio-Products, Inc., San Diego, CA).

\section{SAMPLE PREPARATION}

Prehistorical skeletal remains normally were found and recovered by archaeological excavations. This is significant concerning the following scientific examinations. Finally, only the expert mapping and recovering of the finds allows a successful evaluation of the whole feature. Looking towards a possible aDNA-analysis the way how bones are recovered is very important. To avoid a possible contamination by the excavator (e.g. adhered DNA and DNA decomposing DNase-reaction by contact, recent DNA by sweat or skin scales) it is necessary to wear already at this time latex gloves and face masks. This should be valid for all further steps of bone examination. Unfortunately, although the potential meaning of molecular biological investigations in archaeological research becomes obvious, in practice it comes up rarely to this demand. For this reason several institutions and private excavation companies already started to work hand in hand with specially instructed archaeobiologists, who professionally introduce all required precautions when excavating and recovering prehistoric bones.

Certain areas of the skeletal remains are suitable for DNA extraction. Samples are mainly taken from the diaphysis region of the long extremity bones such as femur, tibia and humerus. Apart from the spongious substances unsuitable for use in the subsequent extractions these consist of solid bone substance, the Compacta. In it, because of its dense structure and under favourable preservation conditions, a sufficient amount of organic components (collagens) remain from which DNA may be isolated. On principle and on the condition that prehistorical DNA is preserved, every other skeletal bone 


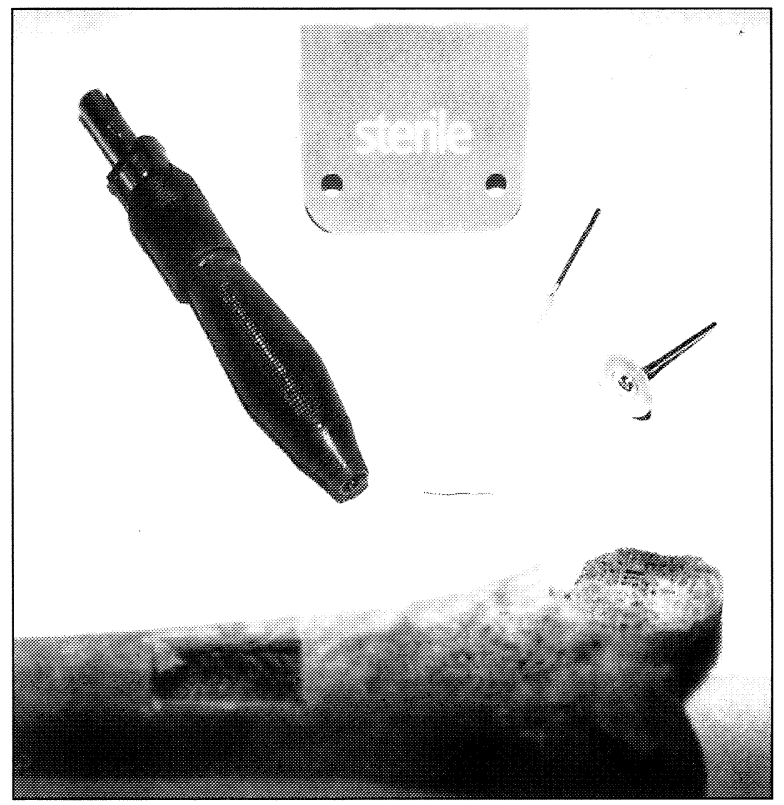

Plate 2. Specific milling and separation tools to remove any possible contamination from the surface of a sample.

sample (e.g. skull, clavicle) can also be used for the extraction of nucleic acids (Scholz and Pusch, 1999).

At the best, the total sample consists of 2 to 3 bone fragments of about 1 to $2 \mathrm{~cm}^{2}$ in order to make up for differences in promising DNA preservation because of the storage conditions. The bone chips are removed with the help of a hand mill (DBP Supra; Kaltenbach \& Voigt/ Biberach) which is normally used in dental clinics. In order to work as exactly as possible the mill has to be fitted with a diamond separation disc (Orthodontros, Ultraflex 912-EF).

After the sample has been removed a slice of about $3 \mathrm{~mm}$ is milled off the sides of each sample in order to remove any contaminands and Spongiosa from the area of the Cavitas medullaris (Plate 2). For this work the mill has to be fitted with a new disc (Orthodontros, milling head of plastic-diamond with 3-layer trianonlining, GD-No. 6830).

The bone samples are then mechanically ground into a fine powder with a vibration mill and sterile agate mortars in order to obtain the largest possible surface for subsequent lysis and extraction steps. After that, the bone powder is transfered into a container with a screw-on top (Falcon BlueMax 2070) and gently mixed. From the sample size described about 6 to $8 \mathrm{~g}$ of bone powder can be obtained. A dry storage at room temperature is the most suitable condition for the bone powder, which is now readily available for further molecular genetic analysis (e.g. PCR, cloning).

\section{CONTAMINATION MONITORING}

To initially test the contamination/purity status of a pulverized bone sample a sensitive and rapid method, based upon elevated levels of D-aspartic acid, D-alanine, D-leucine, D-serine, and D-phenylalanine observed, is required. Approximately 1 $\mathrm{mg}$ of pulverized bone sample (taken from an internal layer of the Compacta unless otherwise indicated) is hydrolyzed in $200 \mu 16 \mathrm{~N} \mathrm{DCl}$ in $\mathrm{D}_{2} \mathrm{O}(24 \mathrm{~h} /$ $110^{\circ} \mathrm{C}$ ), esterified with $200 \mu 11.5 \mathrm{~N} \mathrm{DCl}$ in $\mathrm{CH}_{3} \mathrm{OD}$ $\left(15 \mathrm{~min} / 110^{\circ} \mathrm{C}\right)$ and trifluoroacetylated $(100 \mu \mathrm{l}$ $\mathrm{TFAA} / 10 \mathrm{~min} / 110^{\circ} \mathrm{C}$ ). Insoluble inorganic salts from the bone were largely removed by decanting the TFAA solution containing the dissolved amino acid derivatives into a fresh vial before evaporating off excess TFAA. The amino acid derivatives, dissolved in $10 \mu \mathrm{l}$ toluene, are separated by enantioselective gas chromatography on a Chirasil-Val capillary and detected by mass spectrometric selective ion monitoring using the following ions: $\mathrm{m} / \mathrm{z} 138$ (serine), $\mathrm{m} / \mathrm{z} 140$ (alanine), $\mathrm{m} / \mathrm{z} 156$ (aspartic acid), $\mathrm{m} / \mathrm{z} 182$ (leucine), $\mathrm{m} / \mathrm{z} 214$ (glutamic acid), and $\mathrm{m} /$ z 162 (phenylalanine). The $\mathrm{D} / \mathrm{L}$ ratio of each amino acid can be calculated directly from the respective peak areas. This general technique for racemization control has been described in more detail elsewhere (Gerhardt and Nicholson, 1994).

The degree of racemization of amino acids has been proposed as an indicator for the presence or not of amplifiable authentic DNA in ancient samples (Poinar et alii, 1996). Racemization of aspartate is the principal criterium considered and a threshold of 0.08 for the value of $[\mathrm{D}] /[\mathrm{L}]$ aspartic acid was proposed (Poinar et alii, 1996). Accordingly, samples with higher racemate contents of aspartic acid cannot be expected to contain authentic DNA suitable for amplification, while contamination from more recent times can allegedly be recognized by $\mathrm{D} / \mathrm{L}$ ratios of alanine and leucine being higher than that of aspartic acid (Poinar et alii, 1996). For the detection of glue-based DNA contamination (i.e. introduced by conservation techniques), we further propose three criteria for the assessment of whether or not a bone sample has been treated with glue.

T. P., 57, n. $^{\circ} 1,2000$ 
Criterium 1 is based on the absolute value of $\mathrm{D} /$ $\mathrm{L}$ serine. For example, the mean value for a collection of treated samples $(\mathrm{n}=12)$ was $144.1 \times 10^{-3}$ with a standard deviation of $25.7 \times 10^{-3}$. We therefore propose a threshold of D/L-serine of 92.7.x10${ }^{3}$, which is the lower $95 \%$ confidence limit (i.e. 2 s) for treated samples. Samples with D/L Ser values higher than $92.7 \times 10^{-3}$ must therefore be considered as having probably been treated with glue at least once.

Criterium 2 is described by the ratio of the racemization rate constants of serine to aspartic acid. The absolute value for the racemate content of a specific amino acid in an ancient sample is dependent upon numerous factors most important of which are its age and the temperature and $\mathrm{pH}$ experienced during deposition. Differences in the relative rates of racemization of two amino acids in the same sample on the other hand can reflect differences in the chemical environment (e.g. pH) while eliminating the factor of time. The racemization rate constant is defined as $\mathrm{k}_{\mathrm{rac}}=[\ln (1 / \mathrm{ee})] / 2 \mathrm{t}$-where ee defines: $($ enantiomeric excess $)=([\mathrm{L}]+[\mathrm{D}]) /([\mathrm{L}]-$ $[\mathrm{D}])$, and $\mathrm{t}$ is the abbreviation for time-, given that the racemate content at zero time is zero (c.f. values determined for bone samples of age ca. 2 years : D/ $\mathrm{L}=3.8 \times 10^{-3}$ for Asp and $2.4 \times 10^{-3}$ for Ser). If we form the ratio of the rate constants of two amino acids in the same sample, the factor time (2t) is eliminated. Thus the ratio of the racemization rate constants for serine and aspartic acid are reliably calculated from the corresponding $\mathrm{D} / \mathrm{L}$ ratios determined. For samples treated with glue, the mean of $\mathrm{k}_{\text {ser }} / \mathrm{k}_{\text {asp }}$ was $0.740 \pm 0.040(\mathrm{n}=12)$ while the corresponding value for non-treated samples was $0.480 \pm$ $0.205(n=50)$. As threshold we propose once again the lower $95 \%$ confidence limit of the treated values, i.e. 0.660 . Values of $\mathrm{k}_{\text {ser }} / \mathrm{k}_{\text {asp }}$ higher than 0.660 are indicative of possible contamination with glue. A scatter of values from non-treated samples is not unexpected considering the wide disparity of the deposition environments.

Criterium 3 is based on the ratio of the racemization constants of phenylalanine to glutamic acid. Analogous to criterium 2, an elevated value for the racemization rate constant of phenylalanine relative to that of glutamic acid can indicate contamination with glue. The mean of $\mathrm{k}_{\mathrm{phe}} / \mathrm{k}_{\mathrm{glu}}$ for a collection of treated samples was $1.247_{ \pm 0}^{\text {phe }} 0.212$ while the corresponding value for non-treated reference samples was $0.719 \pm 0.444$. The threshold (lower $95 \%$ confidence limit) for probable contamination with glue is thus 0.828 . The higher level of scatter of both populations results from the inability to determine the low absolute values of racemate content for both Phe and Glu (usually only approximately 1-2\% D enantiomers) with high relative precision.

Criterium 1 carries most weight in an assessment of whether or not a sample is contaminated by certain conservation techniques. In contrast, criteria 2 and 3 show lower reliability. The presence of contamination of doubtful samples may be ruled out by the low absolute values of D/L Ser (approximately $25 \times 10^{-3}$ ). We thus propose that a sample must be considered as contaminated with glue if all three criteria are fulfilled.

Furthermore, it is not only feasible to use samples taken from the bone surface but that differentiation between treated and non-treated bones is in fact clearer on the basis of surface measurements (data not shown). Since only $1 \mathrm{mg}$ substance scraped from an inconspicuous part of the bone surface is sufficient for testing, damage to the specimen is reduced to a minimum.

\section{CONCLUSION}

Summig up, it appears promising when palaeogenetic tools and methodology are introduced to the archaeological research. As already seen in most recent publications, a number of archaeological questions may profit by palaeogenetics, amongst them e.g. approaches for reconstructing prehistoric social structures (i.e. relationship determination) or certain applications in palaeopathological research. Moreover, the repertoire of techniques available for the analysis of even highly degraded fossil DNA will further elucidate features of general biological interest (e.g. evolution of mankind).

Since improved aDNA techniques provide valuable data and thus allow to launch larger research projects, the relatively young discipline of palaeogenetics will establish itself as a further important tool in prehistoric and anthropological research. International scientific collaboration may undoubtlessly lead to a better and also broader acceptance within the involved and also quite different disciplines, and will therefore lead to a high quality research in palaeogenetic sciences. In the future, the increasing exchange of knowledge and experiences of the work groups handling ancient substrates is therefore highly desirable. 


\section{BIBLIOGRAPHY}

Gerhardt, J. and Nicholson, G. (1994): "Chemistry, Structure and Biology”. In R.S. Hodges \& J.A. Smith (eds.): Peptides. Escom. Leiden.

HAGELBERG, E. and ClEGG, J. (1991): "Isolation and characterisation of DNA from archaeological bone". Proceedings of the Royal Society London, B 244: 45-50.

Hauser, G. and De Stefano, G.F. (1989): Epigenetic Variants of the Human Skull. Schweizerbart. Stuttgart.

IZAGIRRE, N.; DURÁN, L.M. and DE LA RÚA, C. (1998): “Genética y arqueología; Análisis molecular de ADN procedente de restos esqueléticos". Munibe, 50: 3-14.

PoINAR, H.N.; Höss, M.; BADA, J.L. and PäÄBO, S. (1996): "Amino acid racemization and the preservation of ancient DNA". Science, 272: 864-866.

Pusch, C.M. and Scholz, M. (1997): "DNA isolation from ancient human bone samples via enzymatic treatment". TechnicalTips Online (http://www.biomednet.com/db/ tto) T0121.

- (1998): "Detecting prehistoric human DNA: Construction and screening of a small scale plasmid library reveals a new repetitive and tandemly organised $25 \mathrm{bp}$ motif". Ancient Biomolecules, 2: 43-61.

Pusch, C.M.; Giddings, I. and Scholz, M. (1998): "Repair of degraded duplex DNA from prehistoric samples using Escherichia coli DNA polymerase I and T4 DNA ligase". Nucleic Acids Research, 26 (3): 857-559.

Sealy, J.C.; VAn der Merwe, N.J.; Sillen, A.; Krueger, F.J. and KRUEGER, H.W. (1991): “"87 $\mathrm{Sr} /{ }^{86} \mathrm{Sr}$ as a dietary indicator in modern and archaeological bone". Journal of Archaeological Science, 18: 399-416.

Scholz, M. (1996): "Eine partiell persistierende Chorda dorsalis an einer frühmittelalterlichen Bestattung aus Neresheim". Bulletin de la Société Suisse d'Anthropologie, 2 (2): 47-53.

SchOlz, M. and Pusch, C. (1997): "An efficient isolation method for high-quality DNA from ancient bones". Te chnical Tips Online (http://www.biomednet.com/db/ tto) T01045.

- (1999): "The Neandertal Find of Neuwarendorf: molecular genetic evidence and perspectives". Bulletin de la Société Suisse d'Anthropologie, 5 (1): 55-61.

Scholz, M.; Czarnetzki, A. and Pusch, C.M. (1997a): "Messages from the past: Relationship determinations on prehistorical total human DNA reveal an extraordinary allele via STR system unknown in previous HumCD4-DNA standard". Poster demonstration at: $5^{\text {th }}$ International Conference on Molecular Biology and Evolution, 1-4 Juni, Garmisch-Partenkirchen (Germany).

Scholz, M.; Hengst, S. and Pusch, C.M. (1997b): "Who is who in ancient societies? Kinship determinations on prehistorical total human DNA". Poster demonstration at: Ancient DNA IV, 5-7 Juni, Göttingen (Germany).

Scholz, M.; Hengst, S. and Pusch, C.M. (1997c): "Genetic determination of family relationship among individuals in an Early Medieval graveyard". Poster demonstration at: Medieval Europe, An International Conference of Medieval and Later Archaeology, 1-4 Oktober, Brugge (Belgium).

Scholz, M.; Giddings, I. and Pusch, C. (1998): "A Polymerase Chain Reaction Inhibitor of ancient hard and soft Tissue DNAExtracts is determined as human Collagen Type I". Analytical Biochemistry, 259: 1-4.

T. P., 57, n. ${ }^{\circ} 1,2000$ 